\title{
Could the Olfactory System Be a Target for Homeopathic Remedies as Nanomedicines?
}

\author{
Florence Courtens, MD, Jean-Louis Demangeat, MD, $\mathrm{PhD}^{2}$ and Mourad Benabdallah, $\mathrm{MD}^{3}$
}

\begin{abstract}
Homeopathic remedies (HRs) contain odorant molecules such as flavonoids or terpenes and can lose their efficiency in presence of some competitive odors. Such similarities, along with extreme sensitivity of the olfactory system, widespread presence of olfactory receptors over all organic tissues (where they have metabolic roles besides perception of odors), and potential direct access to the brain through olfactory nerves (ONs) and trigeminal nerves, may suggest the olfactory system as target for HRs. Recent works highlighted that HRs exist in a dual form, that is, a still molecular form at low dilution and a nanoparticulate form at high dilution, and that remnants of source remedy persist in extremely high dilutions. From the literature, both odorants and nanoparticles (NPs) can enter the body through inhalation, digestive absorption, or through the skin, especially, NPs or viruses can directly reach the brain through axons of nerves. Assuming that HRs are recognized by olfactory receptors, their information could be transmitted to numerous tissues through receptor-ligand interaction, or to the brain by either activating the axon potential of ONs and trigeminal nerves or, in their nanoparticulate form, by translocating through axons of these nerves. Moreover, the nanoparticulate form may activate the immune system at multiple levels, induce systemic various biological responses through the pituitary axis and inflammation factors, or modulate gene expression at the cellular level. As immunity, inflammation, pituitary axis, and olfactory system are closely linked together, their permanent interaction triggered by olfactory receptors may thus ensure homeostasis.
\end{abstract}

Keywords: homeopathy, olfactory system, odorants, nanoparticles

\section{Introduction}

$\mathbf{H}$ OMEOPATHIC REMEDIES (HRs) contain plant, animal, mineral, and metal products with specific odors such as flavonoids and terpenes in plant extracts, for example, ${ }^{1-5}$ and two well-recognized homeopaths, Hahnemann and Schmidt, asked their patients to smell HRs. ${ }^{6-9}$ Odorant molecules (OMs) and HRs share some properties: some OMs can enhance the perception of other OMs, and some odors can inhibit HRs efficiency. ${ }^{6-8,10,11}$ Too, OMs can exhibit different odors depending on the level of concentration in a manner analogous to how HRs can have inverse reaction depending on the level of dilution (hormesis). ${ }^{11,12}$ Some studies have demonstrated effects of HRs through inhalation, ${ }^{13-18}$ but HRs are generally too dilute for an odor to be consciously recognized.
Two hypotheses explain the differential sensitivity of individuals toward OMs, and maybe toward HRs: different levels of olfactory receptors (ORs) gene expression and anatomical differences in the nasal cavity, both resulting from genetic polymorphism. ${ }^{19,20}$ Notion of competitiveness, modifications of electroencephalogram (EEG) during inhalation, and modifications of genes expression, among which those of ORs by high dilutions of Gelsemium, ${ }^{21}$ strongly suggest that ORs can be a target for HRs.

\section{Infinitesimal Dose Medicine}

Up to now, nobody is able to explain the way homeopathy operates and this medicine acting at infinitesimal dose became a subject of distrust and sarcasm. In contrast, nanomedicine is

\footnotetext{
${ }^{1}$ Private Practice, Orchies, France.

${ }^{2}$ Nuclear Medicine Department, General Hospital, Haguenau, France.

${ }^{3}$ Private Practice, Arras, France.
}

(C) Florence Courtens et al. 2018; Published by Mary Ann Liebert, Inc. This Open Access article is distributed under the terms of the Creative Commons Attribution Noncommercial License (http://creativecommons.org/licenses/by-nc/4.0), which permits any noncommercial use, distribution, and reproduction in any medium, provided the original authors and the source are cited. 
expanding rapidly in both allopathic and homeopathic ${ }^{5}$ fields. Recently, several groups ${ }^{1,22-30}$ have highlighted the presence of nanoparticles (NPs) in highly diluted HRs. Bellavite and coworkers described how HRs, at different levels of dilution, can influence immunity and inflammatory factors and even modulate gene expression, ${ }^{2,21}$ based on a ligand-effector type interaction, whereas Bell et al ${ }^{1,28-30}$ suggested a systemic reaction to HRs as stressors. ${ }^{31,32}$

Demangeat ${ }^{33}$ suggested that the two concepts would not contradict each other but rather reflect a dual character of HRs depending on their level of dilution. At low dilution, below $\mathrm{C} 2-\mathrm{C} 4$, HRs in a still molecular nature would act locally on cellular or intracellular receptors, whereas at high dilution, in a nanoparticulate form, they would cross cell membranes and physiological barriers as mucous membranes, lungs, blood-brain barrier ${ }^{5}$ (BBB), or would directly reach the brain through a neural pathway.

\section{The Vomeronasal Organ}

First, Benabdallah ${ }^{34}$ and McGuigan ${ }^{10}$ suggested that the vomeronasal organ (VNO), which is very sensitive and able to induce a stereotypical behavior, could be a target for HRs. In terrestrial animals, most pheromone receptors are located in the $\mathrm{VNO}$, within the nasal cavity, whereas in insects they are located in antennae. ${ }^{35}$ Bombyx pheromone can be detected at exposure levels of about 200 molecules per $\mathrm{cm}^{3}{ }^{3}$ equivalent to a homeopathic dilution between $\mathrm{C} 8$ and $\mathrm{C} 9 .{ }^{35}$ VNO directly interacts with the pituitary axis, bypassing the olfactory cortex and generating hormone secretion that provokes behavior changes: mating, aggression, and parental behavior. ${ }^{36,37}$ Moreover, VNO plays a role in immunity by detecting metabolites produced by endo- or exogenous germs. ${ }^{36,38}$ In humans, VNO develops during fetal stage, then regresses to a vestigial organ, considered as a nonfunctional secondary olfactory organ in adulthood. ${ }^{36-38}$ To date, no human pheromone has been identified with certainty. However, according to some authors, ${ }^{11,39}$ hypothetical human pheromones are sensed by olfactory and gustatory receptors (GRs) and by the trigeminal pathway.

\section{The Olfactory System}

The olfactory system separates the brain from the outside world and keeps us informed about our environment by detecting molecules or other particles, some of which are able to directly reach the brain through the olfactory nerves (ONs) provided they are smaller than the nerve diameters, ${ }^{40,41}$ as some viruses do. ONs connect the nasal cavity to the olfactory bulb $(\mathrm{OB})$ passing the cribriform plate of the ethmoid bone through nerve endings covered with ORs immersed in the nasal epithelium mucus. ${ }^{42}$ The three functions of the olfactory system are sense of smell, immune function, and ONs regeneration. ${ }^{43}$ Molecules of various structure, size, and chemical properties can have an odor. ${ }^{44,45}$

OMs can directly reach the olfactory epithelium by inhalation through the nostrils, or indirectly after food chewing, by the retronasal pathway. ORs activation drives a nerve impulse that reaches first the olfactory glomerulus within $\mathrm{OB}$, and then, through the $\mathrm{ON}$, the cortex, and the thalamus. ${ }^{46-51}$ OB has one of the highest capillary density in the brain. ${ }^{52}$ Human sense of smell can detect extremely low concentrations of odorants, ${ }^{53,54}$ as low as $10^{-18} \mathrm{~g} / \mathrm{L},{ }^{55}$ equivalent to a C9 homeopathic dilution. EEG can show specific changes after inhalation of odorants. ${ }^{56}$ If an odorant is too dilute to be recognized consciously as an odor, it can nonetheless either bind ORs that possess other functions than recognition of a smell ${ }^{43}$ or be unconsciously registered by EEG responses. ${ }^{57} \mathrm{OMs}$ can influence the sympathetic and parasympathetic nervous systems, intellectual activity, ${ }^{58}$ neurotransmitters and neuromodulators levels, and the neuroendocrine system.

OMs can play a role in psychological behaviors as well as in various organic functions, through the endocrine system. ${ }^{37,43,46,47,58-60}$

\section{The Trigeminal Pathway}

The trigeminal nerve directly connects the brain and essentially provides somatosensory feelings within its region of innervation. Detection of irritants takes place at GRs and solitary chemosensory cells located close to the nerve endings, or directly at these nerve endings. ${ }^{61,62}$ Keratinocytes can also participate in trigeminal nerve activation when they release adenosine triphosphate at the vicinity of nerve endings. ${ }^{27,63,64}$ After intranasal administration, rhodamine-labeled microspheres $(20-200 \mathrm{~nm})$ can translocate into the brain through uptake by the ophthalmic and maxillary branches of the trigeminal nerve that supply sensory nerve endings throughout the nasal mucosa. ${ }^{65}$ Less than $200 \mathrm{~nm} \mathrm{NPs},{ }^{41,66,67}$ meningitis virus, ${ }^{65}$ and other pathogens ${ }^{65,68}$ can directly reach the brain through $\mathrm{OB}$ and brainstem ${ }^{20,66,68-70}$ from trigeminal pathway.

\section{Nasal Pathway to Cure Diseases}

The main interest of the nasal pathway is to be noninvasive, and thus has been investigated in numerous studies. $^{20,31,68,71-78}$ For instance, this way is used for desmopressine and sumatriptan that are smelled to treat central diabetes insipidus and migrainous crises, respectively. ${ }^{79}$ In the United States, a flu vaccine is administered by the nasal pathway ${ }^{75,76}$ OMs can boost the immune system ${ }^{58,60,80}$ using direct access to the nasal-associated lymphoid tissue (NALT) and to the systemic blood circulation, notably through communication between the nasal mucosa, the subarachnoid spaces, and the lymph nodes of the neck. ${ }^{20,71}$ Activation of the NALT elicits a strong systemic immune response with antigen-specific IgA that is found within digestive, respiratory, and vaginal mucosae as well as in salivary glands. ${ }^{75}$ Nasal microbiota can impact the immune system, too. ${ }^{75,81}$ After nasal administration, drugs encapsulated in NPs can directly follow the olfactory or the trigeminal nerve toward $\mathrm{OB}$ and, from there, translocate into the central nervous system (CNS). ${ }^{65,71}$ NPs can use either an intracellular or an extracellular pathway, that is, the $\mathrm{ON}$ axon or the cells that envelop the axons of the ONs. ${ }^{20,42,64-67,69,70,82}$

\section{Particularities of ORs}

ORs are G protein-coupled receptors, which are among the most represented receptors in the body ${ }^{83,84}$; their plasticity and ability to change conformation make them very sensitive to various ligands (photons, ions, odorants, amino acids, fatty acids, neurotransmitters, peptides, and polypeptides) as well as to $30 \%-40 \%$ of medicines. ${ }^{84,85}$ ORs are not located exclusively in the nasal cavity but widespread 
over all organic tissues (ectopic ORs). ${ }^{19,41,45,47,55,83,86-99}$ In humans, olfactory and hormonal systems are related to each other. ${ }^{19,45,47,50,58,60,100}$ Ectopic ORs have a local action not linked with CNS. At the kidney level, they control blood pressure based on the level of short-chain fatty acids produced by the gut microbiota. ${ }^{88}$ Like ORs, GRs exist on several organic tissues (digestive, respiratory, genitourinary tracts, brain, and immunity cells) where they have other functions beside perception of taste. ${ }^{37,101-105}$

\section{Homeopathy as Nanomedicine}

HRs may take two forms depending on dilution levels. Low dilutions, below $\mathrm{C} 2-\mathrm{C} 4$, could still contain molecules in ponderable and subponderal amounts and bind specific targets as conventional remedies do, whereas high dilutions could contain the active ingredient in nanoparticulate forms that contain silica and nanobubbles, produced by shaking the remedy during the specific dynamization procedure of manufacturing. Assuming that such nanoparticulate forms of HRs possess similar properties as conventional NPs, they would exhibit much higher bioavailability, membrane permeability, and intracellular reactivity than the molecular form. ${ }^{106,107}$ Such properties drastically depend on NPs size, shape, charge surface, and lipophilicy. ${ }^{108,109}$ It has been shown by Demangeat ${ }^{33}$ that sizes of nanostructures in HRs depend of the level of dilution/dynamization. So, the structural duality may explain various and even paradoxical actions of HRs according to their dilution levels.

\section{Link Between OMs and NPs, and Potential Actions of HRs}

Both OMs and NPs can enter the body through inhalation, digestive absorption, or across the skin. ${ }^{41}$ They can potentially directly reach all ORs located on organic tissues except those of the brain, which can be reached only through the ONs and trigeminal nerves or by crossing the BBB. ${ }^{31,59,110-114}$ The diameter of individual axons of the ON does not exceed 100 $200 \mathrm{~nm}$, meaning that this way of translocation only concerns elements with sizes $<100-200 \mathrm{~nm}$. As demonstrated several years ago, polio virus and other NPs can translocate from the nose to $\mathrm{OB}^{65,114}$ and then be found within microglia and in deeper brain regions. ${ }^{69}$ NPs have another toxicity profile, new target organs, and a higher influx to the brain than the bulk material. ${ }^{40,51,67,111}$

Inhaled NPs can penetrate into the lung interstitial tissue where they can be stored for years. The biological half-time of solid particles in the alveolar region is about 700 days in humans. ${ }^{65}$ From there, they can slowly diffuse toward all organs including the brain through the systemic blood circulation or the lymphatic vessels. ${ }^{110,112}$ NPs can induce various biological responses: inflammatory response, oxidative stress, modulation of gene expression, effects on cell cycle control, and proliferation. ${ }^{109}$ NPs can be recognized by the immune system, following any route of uptake into the organism. ${ }^{65}$ Modifications of DNA and noncoding RNA have been shown for cells repeatedly exposed to NPs. Such epigenetic modifications may be very stable and sometimes pass on from one generation to another. ${ }^{115}$ Microglia is sensitive to disturbances in the CNS. ${ }^{113}$ For example, the nasal instillation of NPs generates pathological changes in hippocampus, striatum, and $\mathrm{OB}$, such as proliferation of microglia after uptake of $20 \mathrm{~nm} \mathrm{Ag-NPs.}{ }^{113,116,118}$
Repeated exposure to NPs causes oxidative stress, cytotoxicity, and autophagy, ${ }^{119}$ suppresses inflammation, and secretes proinflammatory cytokines. ${ }^{112,120}$ Cytokines, as IL-1, can be directly produced by microglia and act on the pituitary axis, ${ }^{121}$ which can, in turn, activate the immune system with its hormones secretion such as cortisol. ${ }^{121}$ Leucocytes also possess adrenalin, steroids, insulin, prolactin, growth hormone, and thyroxine receptors. Lymphoid organs hold sympathetic and cholinergic nerve endings and leucocytes possess catecholamine, endorphin, enkephalin, substance $\mathrm{P}$, somatostatin, and vasoactive intestinal peptide receptors. ${ }^{122}$ The brain, organs, and cells continuously interact and communicate with each other to adapt to all kinds of stress. ${ }^{19,88,121,123-125}$

When a stress stimulates the vegetative nervous system, the neuroendocrine system is activated and, if the stress persists, diseases may occur in various distant organs. Cognitive and emotional centers are also linked to the digestive tract through the gut microbiota. ${ }^{80,126,127}$

\section{Conclusion}

The olfactory system is the main gateway to reach the brain and the immune system, and ORs are widespread on all organic tissues; thus, the olfactory system could constitute a suitable explanation for central, local, and immune action of HRs. Moreover, clinical effects are observed for HRs administered through inhalation, and HRs exhibit similar properties as OMs. The complex reality of homeopathy may be explained by the specific manufacturing process of dilution/dynamization, which generates different structural properties of the remedy according to the level of dilution, especially nanoparticulate forms at high dilution. The present speculations only constitute a clue that raises many questions and prompts to further investigations, such as (1) tracking homeopathic NPs through the nerves and into the brain by animal studies, (2) studying EEG responses to various dilutions of a definite HR, (3) identifying immune responses from the NALT, or (4) directly studying the action of HRs on ORs from different tissues by in vitro studies.

\section{Author Disclosure Statement}

No competing financial interests exist.

\section{References}

1. Bell IR, Sarter B, Koithan M, et al. Integrative nanomedicine: Treating cancer with nanoscale natural products. Global Adv Health Med 2014;3:36-53.

2. Olioso D, Marzotto M, Bonafini C, et al. Arnica montana effects on gene expression in a human macrophage cell line. Evaluation by quantitative real-time PCR. Homeopathy 2016;105:131-147.

3. Guermonprez M, Pinkas M, Torck M. Materia media homeopathic [in French]. 3rd ed. Sainte-Foy-lès-Lyon: Boiron Ed, 2005.

4. Wani K, Shah N, Prabhune A, et al. Evaluating the anticancer activity and nanoparticulate nature of homeopathic preparations of Terminalia chebula. Homeopathy 2016; 105:318-326.

5. Zubedat S, Freed Y, Eshed Y, et al. Plant-derived nanoparticle treatment with Cocc 30C ameliorates attention 
and motor abilities in sleep-deprivated rats. Neuroscience 2013;253:1-8.

6. Hahnemann S. Organon of medicine [In French]. Translated by Roy RC from German (Haehl R, 6th ed., 1921). Sainte-Foy-lès-Lyon: Boiron ed, 2014.

7. Hahnemann S. Materia medicuria pura [in French]. Translated by Jourdan AJL from German. Sainte-Foy-lèsLyon: Similia Ed, 1989.

8. Baur J. The teaching of doctor Schmidt [In French]. Tome 2. Sainte-Foy-lès-Lyon: Similia Ed, 1991.

9. Rabanes O. The repetition of homeopathic medicines according to Hahnemann [In French]. Revue d'Homéopathie 2017;8:174-178.

10. McGuigan M. Hypothesis: Do homeopathic medicines exert their action in humans and animals via the vomeronasal system? Homeopathy 2007;96:113-119.

11. McGuigan M. Observations on the effects of odours on the homeopathic response. Homeopathy 2014;103:198202.

12. Courtens F. Homeopathy, "l'air de rien" or homeopathy, volatil non odorant molecule and olfactory receptors [in French]. Université Lille 2 Droit et Santé. Thesis, Lille, 2016. DOI: 10.13140/RG.2.2.14543.48809.

13. Bell IR, Brooks AJ, Howerter A, et al. Short-term effects of repeated olfactory administration of homeopathic Sulphur and Pulsatilla on electroencephalographic alpha power in healthy young adults. Homeopathy 2011;100: 203-211.

14. Bell IR, Howerter A, Jackson N, et al. Multiweek resting EEG cordance change patterns from repeated olfactory activation with two constitutionally salient homeopathic remedies in healthy young adults. J Altern Complement Med 2012;8:445-453.

15. Bell IR, Lewis DA, II, Lewis SE, et al. EEG Alpha sensitization in individualized homeopathic treatment of fibromyalgia. Int J Neurosci 2004;114:1195-1220.

16. Bell IR, Lewis DA, Schwartz GE et al. Electroencephalographic cordance patterns distinguish exceptional clinical responders with fibromyalgia to individualized homeopathic medicines. J Altern Complement Med 2004;10:285-299.

17. Fernandez M, Bell IR, Schwartz GE. EEG sensitization during chemical exposure in women with and without chemical sensitivity of unknown etiology. Toxicol Ind Health 1999; 15:305-312.

18. Ferrari de Andrade L, Mozeleski B, LeckAR, et al. Inhalation therapy with M1 inhibits experimental melanoma development and metastases in mice. Homeopathy 2016; 105:109-118.

19. Abaffy T. Human olfactory receptors expression and their role in non-olfactory tissues, a mini-review. J Pharmacogenomics Pharmacoproteomics 2015;6:152.

20. Lochhead JJ, Thorne RG. Intranasal delivery of biologics to the central nervous system. Adv Drug Deliv Rev 2012; 64:614-628.

21. Marzotto M, Olioso D, Brizzi M, et al. Extreme sensitivity of gene expression in human SH-SY5Y neurocytes to ultra-low doses of Gelsemium sempervirens. BMC Complement Altern Med 2014;14:104.

22. Rajendran ES. An evaluation of Avogadro's number in the light of HRTEM and EDS studies of high dilutions of Ferrum metallicum 6, 30, 200, 1M, 10M and $50 \mathrm{Mc}$. Int J High Dilution Res 2015;14:3-9.

23. Rajendran ES. Homeopathy a material science: Nanoparticle characterization of Aurum metallicum 6C, 30C,
200C, 1000C, 10000C, 50000C and 100000C. Int J Curr Res 2017;9:48923-48927.

24. Chikramane PS, Suresh AK, Bellare JR, Kane SG. Extreme homeopathic dilutions retain starting materials: A nanoparticulate perspective. Homeopathy 2010;99:231-242.

25. Chikramane PS, Kalita D, Suresh AK, et al. Why extreme dilutions reach non-zero asymptotes: A nanoparticulate hypothesis based on froth flotation. Langmuir 2012;28: 15864-15875.

26. Chikramane PS, Suresh AK, Kane SG, Bellare JR. Metal nanoparticle induced hormetic activation: A novel mechanism of homeopathic medicines. Homeopathy 2017;106: 135-144.

27. Temgire MK, Suresh AK, Kane SG, Bellare JR. Establishing the interfacial nano-structure and elemental composition of homeopathic medicines based on inorganic salts: A scientific approach. Homeopathy 2016;105:160 172.

28. Bell IR, Koithan M. A model for homeopathic remedy effects: Low dose nanoparticles, allostatic cross-adaptation, and time-dependent sensitization in a complex adaptive system. BMC Complement Altern Med 2012;12:191.

29. Bell IR, Koithan M, Brooks AJ. Testing the nanoparticleallostatic cross-adaptation-sensitization model for homeopathic remedy effects. Homeopathy 2013;102:66-81.

30. Bell IR, Schwartz GE, Frye J, et al. Extending the adaptive network nanomedicine model for homeopathic medicines: Nanostructures as salient cell danger signals for adaptation. Nanosci Technol 2015;2:1-22.

31. Bellavite P, Marzotto M, Olioso D, et al. High-dilution effects revisited. 2. Pharmacodynamic mechanisms. Homeopathy 2014;103:22-43.

32. Bellavite P, Signorini A, Marzotto M, et al. Cell sensitivity, non-linearity and inverse effects. Homeopathy 2015; 104:139-160.

33. Demangeat JL. Towards a rational insight into the paradox of homeopathy. Adv Complement Alt Med. 2018;2.

34. Benabdallah M. Homeopathic chronicles: Some principles and digressions. Pheromones and homoeopathy [in French]. Paris: Ellebore Ed, 2007:140-145.

35. Celani A, Villermaux E, Vergassola M. Odor landscapes in turbulent environments. Phys Rev X 2014;4:041015041032.

36. Liberles SD. Mammalian pheromones. |Annu Rev Physiol 2014;76:151-175.

37. Wyatt TD. The search for human pheromones: The lost decades and the necessity of returning to first principles. Proc R Soc B 2015;282:2014-2994.

38. Trotier D. Vomeronasal organ and human pheromones. Eur Ann Otorhinolaryngol Head Neck Dis 2011;128:184190.

39. Doty RL. Human pheromones do they exist? In: MucignatCaretta C, eds. Neurobiology of Chemical Communication. Boca Raton, FL: CRC Press/Taylor \& Francis, 2014: Chapter 19:535-557.

40. Mistry A, Stolnik S, Illum L. Nose-to-brain delivery: Investigation of the transport of nanoparticles with different surface characteristics and sizes in excised porcine olfactory epithelium. Mol Pharm 2015;12: 2755-2766.

41. Patchin ES, Anderson DS, Silva RM, et al. Size-dependent deposition, translocation, and microglial activation of inhaled silver nanoparticles in the rodent nose and brain. Environ Health Perspect 2016;124:1870-1875. 
42. Mauro M, Crosera M, Bovenzi M, et al. Pilot study on in vitro silver nanoparticles permeation through meningeal membrane. Colloids Surf B Biointerfaces 2016;146: 245-249.

43. Ferrer I, Garcia-Esparcia P, Carmona M, et al. Olfactory receptors in non-chemosensory organs: The nervous system in health and disease. Front Aging Neurosci 2016;8: 163.

44. Rodriguez I, Carleton AJ, Rossier D. Methods for identifying a receptor for a ligand and uses. Brevets wo 2016030378A1, BIB-TeX, EndNote, Ref Man, 2016. Online document at: www.google.com/patents/WO2016030378A1?cl=un, accessed November 10, 2017.

45. Pick H, Etter S, Baud O, et al. Dual activities of odorants on olfactory and nuclear hormone receptor. J Biol Chem 2009;284:30547-30555.

46. Hosoi J, Tsuchiya T. Regulation of cutaneous allergic reaction by odorant inhalation. J Invest Dermatol 2000; 114:541-544.

47. Kang N, Yil Bahk Y, Lee N, et al. Olfactory receptor Olfr544 responding to azelaic acid regulates glucagon secretion in a-cells of mouse pancreatic islets. Biochem Biophys Res Commun 2015;460:616-621.

48. Martinez-Marcos A. On the organization of olfactory and vomeronasal cortices. Prog Neurobiol 2009;87:21-30.

49. Leffingwell JC. Olfaction-update No. 5, Leffingwell reports. 2002;2:1-35. Online document at: www.leffingwell. com/download/Olfaction5.pdf, accessed March 15, 2017.

50. Tromelin A. Odour perception: A review of an intricate signalling pathway. Flavour Fragr J 2016;31:107-119.

51. Jia H, Pustovyy OM, Wang Y et al. Enhancement of odorinduced activity in the canine brain by zinc nanoparticles: A functional MRI study in fully unrestrained conscious dogs. Chem Senses 2016;41:53-67.

52. Tucker K, Cho S, Thiebaud N, et al. Glucose sensitivity of mouse olfactory bulb neurons is conveyed by a voltagegated potassium channel. J Physiol 2013;591:2541-2561.

53. Sarrafchi A, Odhammer AM, Hernandez Salazar LT, Laska M. Olfactory sensitivity for six predator odorants in CD-1 mice, human subjects, and spider monkeys. PLoS One 2013;8:e80621.

54. Lee SH, Kwon OS, Song HS, et al. Mimicking the human smell sensing mechanism with an artificial nose platform. Biomaterials 2012;33:1722-1729.

55. Meierhenrich U, Golebiowski J, Fernandez X, CabrolBass D. From molecule to smell, the molecular bases of the first stages of the olfaction [in French]. L'Act Chim 2005;289:29-40.

56. Skorić MK, Adamec I, Jerbić AB, et al. Electroencephalographic response to different odors in healthy individuals: A promising tool for objective assessment of olfactory disorders. Clin EEG Neurosci 2015;46:370-376.

57. Schwartz GE, Bell IR, Dikman ZV, et al. EEG responses to low-level chemicals in normals and cacosmics. Toxicol Ind Health 1994;10:633-643.

58. Angelucci FL, Silva VV, Dal Pizzol C, et al. Physiological effect of olfactory stimuli inhalation in humans: An overview. Int J Cosmet Sci 2014;36:117-123.

59. Lungare S, Hallam K, Badhan RKS. Phytochemicalloaded mesoporous silica nanoparticles for nose-to-brain olfactory drug delivery. Int J Pharm 2016;513:280-293.

60. Kiecolt-Glaser JK, Graham JE, Malarkey WB, et al. Olfactory influences on mood and autonomic, endocrine, and immune function. Psychoneuroendocrinology 2008;33:328-339.
61. Tizzano M, Cristofoletti M, Sbarbati A. Expression of taste receptors in solitary chemosensory cells of rodent airways. BMC Pulm Med 2011;11:3.

62. Tizzano M, Gulbransen BD, Vandenbeuch A, et al. Nasal chemosensory cells use bitter taste signaling to detect irritants and bacterial signals. Proc Natl Acad Sci U S A 2010;107:3210-3215.

63. Yu XC, Yang JJ, Jin BH, et al. A strategy for bypassing the blood-brain barrier: Facial intradermal brain-targeted delivery via the trigeminal nerve. J Control Release 2017; 258:22-23.

64. Sondersorg AC, Busse D, Kyereme J, et al. Chemosensory information processing between keratinocytes and trigeminal neurons. J Biol Chem 2014;289:17529-17540.

65. Oberdörster G, Oberdörster E, Oberdörster J. Nanotoxicology: An emerging discipline evolving from studies of ultrafine particles. Environ Health Perspect 2005;113: 823-839.

66. Kanazawa T. Brain delivery of small interfering ribonucleic acid and drugs through intranasal administration with nanosized polymer micelles. Med Devices 2015;8: 57-64.

67. Garcia GJM, Schroeter JD, Kimbell JS. Olfactory deposition of inhaled nanoparticles in humans. Inhal Toxicol 2015;27:394-403.

68. St John JA, Walkden H, Nazareth L, et al. Burkholderia pseudomallei rapidly infects the brain stem and spinal cord via the trigeminal nerve after intranasal inoculation. Infect Immun 2016;84:2681-2688.

69. Dhuria SV, Hanson LR, Frey WH. Intranasal delivery to the central nervous system: Mechanisms and experimental considerations. J Pharm Sci 2010;99:1654-1673.

70. Chapman CD, Frey WH, Craft S, et al. Intranasal treatment of central nervous system dysfunction in humans. Pharm Res 2013;30:2475-2484.

71. Thorne RG, Emory CR, Ala TA, Frey WH, 2nd. Quantitative analysis of the olfactory pathway for drug delivery to the brain. Brain Res 1995;692:278-282.

72. Krishnan JKS, Arun P, Chembukave B, et al. Effect of administration method, animal weight and age on the intranasal delivery of drugs to the brain. J Neurosci Methods 2017;286:16-21.

73. Simkó M, Mattsson MO. Risks from accidental exposures to engineered nanoparticles and neurological health effects: A critical review. Part Fibre Toxicol 2010;7:42.

74. Sinani G, Sessevmez M, Koray Gök M, et al. Nasal vaccination with poly( $\beta$-aminoester)-poly(D,L-lactide-co-glycolide) hybrid nanoparticles. Int J Pharm 2017;529:1-14.

75. Sepahi A, Salinas I. The evolution of nasal immune systems in vertebrates. Mol Immunol 2016;69:131-138.

76. Pardeshi CV, Kulkarni AD, Belgamwar VS, Surana SJ. Intranasal delivery of nano neurotherapeutics: A meta opinion. Glob J Nano 2017;1:555565.

77. Devissaguet JP, Brion N, Lhote O, Deloffre P. Pulsed estrogen therapy: Pharmacokinetics of intranasal 17-betaestradiol (S21400) in postmenopausal women and comparison with oral and transdermal formulations. Eur J Drug Metab Pharmacokinet 1999;24:265-271.

78. Rudin A, Riise GC, Holmgren J. Antibody responses in the lower respiratory tract and male urogenital tract in humans after nasal and oral vaccination with cholera toxin B subunit. Infect Immun 1999;67:2884-2890.

79. Bernocchi B. Porous maltodextrin nanoparticles for the intranasal delivery of vaccines. Human health and pa- 
thology. Université du Droit et de la Santé-Lille II, 2016. English. Online document at: https://tel.archives-ouvertes. fr/tel-01480950, accessed August 8, 2017.

80. Ainai A, Suzuki T, Tamura S, Hasegawa H. Intranasal administration of whole inactivated influenza virus vaccine as a promising influenza vaccine candidate. Viral Immunol 2017;30:451-462.

81. Montiel-Castro AJ, González-Cervantes RM, BravoRuiseco G, Pacheco-Lopez G. The microbiota-gut-brain axis: Neurobehavioral correlates, health and sociality. Front Integr Neurosci 2013;7:70.

82. Macedo-Ramos H, Ruiz-Mendoza S, Mariante RM. Streptococcus pneumoniae resists intracellular killing by olfactory ensheathing cells but not by microglia. Sci Rep 2016;6:36813.

83. Sanz G, Leray I, Grébert D, et al. Structurally related odorant ligands of the olfactory receptor OR51E2 differentially promote metastasis emergence and tumor growth. Oncotarget 2017;17:4330-4341.

84. Millar RP, Newton CL. The year in G protein-coupled receptor research. Mol Endocrinol 2010;24:261-274.

85. Alfonzo-Méndez MA, Alcántara-Hernández R, GarcíaSáinz JA. Novel structural approaches to study GPCR regulation. Int J Mol Sci 2017;18:27.

86. Aisenberg WH, Huang J, Zhu W, et al. Defining an olfactory receptor function in airway smooth muscle cells. Sci Rep 2016;6:38231.

87. Teixeira CS, Cerqueira NM, Ferreira AC. Unravelling the olfactory sense: From the gene to odor perception. Chem Senses 2016;41:105-121.

88. Pluznick JL, Protzko RJ, Gevorgyan H, et al. Olfactory receptor responding to gut microbiota-derived signals plays a role in renin secretion and blood pressure regulation. Proc Natl Acad Sci U S A 2013;110:4410-4415.

89. Kang N, Koo J. Olfactory receptors in non-chemosensory tissues. BMB Rep 2012;45:612-622.

90. Le Bon A-M, Tromelin A, Thomas-Danguin T, Brian L. The olfactory receiptors and the coding of smell [in French]. Cah Nutr Diet 2008;43:282-288.

91. Maßberg D, Simon A, Häussinger D, Hatt $H$. Monoterpene(-)-citronellal affects hepatocarcinoma cell signaling via an olfactory receptor. Arch Biochem Biophys 2015;566:100-109.

92. Lim JH, Park J, Oh EH, et al. Nanovesicle-based bioelectronic nose for the diagnosis of lung cancer from human blood. Adv Healthc Mater 2014;3:360-366.

93. Chang A-J, Ortega F-E, Riegler J, et al. Oxygen regulation of breathing through an olfactory receptor activated by lactate. Nature 2015;527:240-244.

94. Feldmesser E, Olender T, Khen M, et al. Widespread ectopic expression of olfactory receptor genes. BMC Genomics 2006;7:121.

95. Flegel C, Manteniotis S, Osthold S, et al. Expression profile of ectopic olfactory receptors determined by deep sequencing. PLoS One 2013;8:e55368.

96. Kim SH, Yoon YC, Lee AS, et al. Expression of human olfactory receptor $10 \mathrm{~J} 5$ in heart aorta, coronary artery, and endothelial cells and its functional role in angiogenesis. Biochem Biophys Res Commun 2015;460:404408.

97. Malki A, Fiedler J, Fricke K, et al. Class I odorant receptors, TAS1R and TAS2R taste receptors, are markers for sub-populations of circulating leukocytes. J Leukoc Biol 2015;97:533-545.
98. Busse D, Kudella P, Grüning NM, et al. A synthetic sandalwood odorant induces wound- healing processes in human keratinocytes via the olfactory receptor OR2AT4. J Invest Dermatol 2014;134:2823-2832.

99. Sanz G, Leray I, Dewaele A, et al. Promotion of cancer cell invasiveness and metastasis emergence caused by olfactory receptor stimulation. PLoS One 2014;9: e85110.

100. Lu P, Zhang C-H, Lifshitz LM, ZhuGe R. Extraoral bitter taste receptors in health and disease. J Gen Physiol 2017; 149:181-197.

101. Mosinger B, Redding KM, Rockwell Parker M, Margolskee RF. Genetic loss or pharmacological blockade of testes-expressed taste genes causes male sterility. Proc Natl Acad Sci U S A 2013;110:12319-12324.

102. Gaida MM, Mayer C, Dapunt U, et al. Expression of the bitter receptor T2R38 in pancreatic cancer: Localization in lipid droplets and activation by a bacteria-derived quorumsensing molecule. Oncotarget 2016;7:12623-12632.

103. Eberle JA-M, Widmayer P, Breer H. Receptors for shortchain fatty acids in brush cells at the "gastric groove." Front Physiol 2014;5:152.

104. Wu SV, Rozengurt N, Yang M, et al. Expression of bitter taste receptors of the T2R family in the gastrointestinal tract and enteroendocrine STC-1 cells. Proc Natl Acad Sci U S A 2002;99:2392-2397.

105. Sbarbati A, Osculati F. The taste cell-related diffuse chemosensory system. Prog Neurobiol 2005;75:295-307.

106. Rajendran ES. Field emission scanning electron microscopic (FESEM) and energy dispersive spectroscopic (EDS) studies of centesimal scale potencies of the homeopathic drug Lycopodium clavatum. AJHM Spring 2015;108:9-17.

107. Roduner E. Size matters: Why nanomaterials are different. Chem Soc Rev 2006;35:583-592.

108. Dawson AK, Salvaty A, Lynch I. Nanotoxicology: Nanoparticles reconstruct lipids. Nat Nanotechnol 2009;4: $84-85$.

109. Marano F, Hussain S, Rodrigues-Lima F, et al. Nanoparticles: Molecular targets and cell signalling. Arch Toxicol 2011;85:733-741.

110. Pujalté I, Dieme D, Haddad S, et al. Toxicokinetics of titanium dioxide $\left(\mathrm{TiO}_{2}\right)$ nanoparticles after inhalation in rats. Toxicol Lett 2017;265:77-85.

111. Ahmad E, Feng Y, Qi J, et al. Evidence of nose-to-brain delivery of nanoemulsions: Cargoes but not vehicles. Nanoscale 2017;9:1174-1183.

112. Song B, Zhou T, Liu J, Shah L. Involvement of programmed cell death in neurotoxicity of metallic nanoparticles: Recent advances and future perspectives. Nanoscale Res Lett 2016;11:484.

113. Wang Y, Wang B, Zhu M-T, et al. Microglial activation, recruitment and phagocytosis as linked phenomena in ferric oxide nanoparticle exposure. Toxicol Lett 2011;205:26-37.

114. Buzea C, Pacheco Blandino II, Robbie K. Nanomaterials and nanoparticles: Sources and toxicity. Biointerphases 2007;2:MR17-MR71.

115. Sierra MI, Valdés A, Fernández AF, et al. The effect of exposure to nanoparticles and nanomaterials on the mammalian epigenome. Int J Nanomedicine 2016;11:6297-6306.

116. Ducray AD, Stojiljkovic A, Möller A, et al. Uptake of silica nanoparticles in the brain and effects on neuronal differentiation using different in vitro models. Nanomedicine 2017;13:1195-1204. 
117. Hutter E, Boridy S, Labrecque S, et al. Microglial response to gold nanoparticles. ACS Nano 2010;4:25952606.

118. Lalancette-Herbert M, Phaneuf D, Soucy G, et al. Live imaging of Toll-like receptor 2 response in cerebral ischaemia reveals a role of olfactory bulb microglia as modulators of inflammation. Brain 2009;132:940-954.

119. Marquardt C, Fritsch-Decker S, Al-Rawi M, et al. Autophagy induced by silica nanoparticles protects RAW264.7 macrophages from cell death. Toxicology 2017;379: 40-47.

120. Chen RJ, Lee YH, Yeh YL, et al. The roles of autophagy and the inflammasome during environmental stresstriggered skin inflammation. Int J Mol Sci 2016;17:2063.

121. Bonamin LV. Discovering How Homeopathy Works (1st ed.), English version. São Bernardo do Campo: Eliana Aparecida Perrone, Biodilutions Ed, 2016.

122. Merlot E. Consequences of the stress on the immunizing function to farmed animals [in French]. INRA Prod Anim 2004; 17:255-264.

123. Dei A, Bernardini S. Hormetic effects of extremely diluted solutions on gene expression. Homeopathy 2015; 104:116-122.
124. Carabotti M, Scirocco A, Maselli MA, Severi C. The gutbrain axis: Interactions between enteric microbiota, central and enteric nervous systems. Ann Gastroenterol 2015; 28:203-209.

125. Bhatnagar V, Richard EL, Wu W, et al. Analysis of ABCG2 and other urate transporters in uric acid homeostasis in chronic kidney disease: Potential role of remote sensing and signaling. Clin Kidney J 2016;9:444-453.

126. Natarajan N, Pluznick JL. Olfaction in the kidney: Smelling' gut microbial metabolites. Exp Physiol 2016;101:478-481.

127. Pluznick JL. A novel SCFA receptor, the microbiota, and blood pressure regulation. Gut Microbes 2014;5:202-207; Addendum to: ref 87.

Address correspondence to:

Florence Courtens, MD

Private Practice

18 avenue de la libération

59310 Orchies

France

E-mail: florence.courtens@gmail.com 